\title{
CONCEPTUAL APPROACH TO UNDERSTANDING BUDGET MANAGEMENT IN THE PUBLIC REGULATION SYSTEM
}

\author{
Nataliia Melnychuk', Svitlana Zalyubovska²
}

\begin{abstract}
Based on the generalization of existing conceptual approaches to the budget management understanding in the public regulation system, a conceptual approach «Entity-Relationship-Result» Management is proposed, which made it possible to reveal the main trends in the budget management development in the public regulation system, determine its structural elements, deepen the budget management essence, characterize scientific approaches to understanding the components and principles of budget management, state your own vision of its methods and classification features. From this, a conceptual semantic model of the budget management understanding in the public regulation system is developed reflecting the list of budget management components in the public regulation system, their close relationship and coherence. The purpose of the article is the development of a conceptual approach to the budget management development in the public regulation system. Theoretical and methodological principles of the budget management development in the public regulation system is a subject of investigation. Research design. Within the article, a set of general scientific and special research methods is used. When forming the conceptual categorical apparatus, methods of analysis and synthesis, generalization and scientific abstraction were used. Abstract-logical method was used for the generalization of theoretical foundations of budget management; system analysis was used to characterize the main components, functions, principles, techniques and budget management methods; historical-logical method, the method of induction and deduction allowed to explore the conceptual approach to understanding the importance of budget management in the public regulation system; graphical method was used to visualize the results of the study. Conclusions. Therefore, budget management is one of the tools to overcome problems, which arise in the process of formation and use of budget funds in the conditions of their scarcity. The matter of justification of optimal and effective methods and tools of effective budgetary management is important not only for Ukraine but also for other states, in particular the post-Soviet space. At the same time, the global experience does not give universal decisions on the budget management organization, since each state has its own budgetary system, peculiarities of building a budgetary system and its conceptual management approaches that can be used in the budgetary sphere (New Public Management, Good Governance, Multi-level Governance, Network Management and E-government). It is proved that, although budget management is widely used in financial science, a conceptual approach to its understanding has not been formed yet. Critical analysis of the literature has made it possible to substantiate that in the study of budget management, conceptual approaches of public administration are used, which do not allow revealing all its peculiarities in full. We have offered our own conceptual approach «Entity-Relationship-Result» Management, which made it possible to reveal the main trends in the budget management development in the public regulation system; determine its structural elements, deepen the budget management essence (a complex of interrelated functions, principles, methods, techniques and procedures used by the authorized bodies and aimed the development and implementation of management decisions in drawing up, reviewing, approving, executing the state budget and the budgets of its territorial and administrative units to ensure efficient use of budgetary funds), offer scientific approaches to understanding the components and principles of budget management, state your own vision of its methods and classification features. This helped to build a conceptual semantic model of understanding budget management
\end{abstract}

\footnotetext{
Corresponding author:

${ }^{1}$ National Academy of Statistics, Accounting and Auditing, Ukraine.

E-mail: natasha_shevchuk_2012@ukr.net

ORCID: https://orcid.org/0000-0001-9410-3614

ResearcherID: H-2935-2018

${ }^{2}$ National Academy of Statistics, Accounting and Auditing, Ukraine.

E-mail: zalyubovskaya@bigmir.net

ORCID: https://orcid.org/0000-0001-5651-8165

ResearcherID: K-6235-2018
} 
in the public regulation system. The proposed model reflects the list of budget management components in the public regulation system, their close relationship and coherence, and which are aimed at ensuring the functions performance of public authorities and local self-government bodies.

Key words: budget management, budget, state regulation, public finances, budgetary funds, public regulation.

JEL Classification: H73, H79

\section{Introduction}

The problem of finding optimal and efficient methods and instruments on effective management of public finances is urgent not only for Ukraine, but also for practically all countries of the world. At the same time, the global experience does not give universal decisions on such management, since in each state, there are its own individual budgetary system, peculiarities of budgetary system construction, resources of all levels of government, methods and mechanisms of management. Creating a new type of economy and pursuing structural reforms that would improve the quality of life in recent years by market economy foundations, the budget system stability (Bogolib, 2015) and improving the management effectiveness are required. Reforming the national economy necessitates a modification of budget management, causing, in particular, the change of its subjects in the direction of expanding their competence and placing greater responsibility on them. Activity of any public authority should be productive and transparent. Providing quality services with optimal costs, as well as transparent activity and clear accountability should be their main goal for the population (Babinova, 2007).

This issue is attracting the attention of experts from around the world. Budget management in the public regulation system is investigated by leading economists and scientists, in particular: Bogolib T., Demyanyshyn V., Klets L., Mykhailenko S., Oparin V., Hokayema J., Kairouzb A., Juncos A., Pomorska K., Marks G., and others. However, despite the continued focus on research by scientists and practitioners alike, nevertheless, conceptual approaches to the budget management development in the public regulation system have not yet been formed and its place in the development of strategic principles of budgetary policy has not been clarified. Dependence of the country's social and economic development on budget management is complex and ambiguous. When forming the state budget, it is necessary to develop approaches that take into consideration the balance of different public interests.

The purpose of the article is the development of a conceptual approach to the budget management development in the public regulation system.

In accordance with the stated goal the following tasks were solved: investigate the legislative framework for the budget management development; study the essence of the economic concept «budget management»; determine the purpose of budget management; investigate the object and subjects of budget management; identify the main components of budget management; justify budget management functions; study principles of methods, procedures and techniques of budget management; offer classification features of budget management; develop own conceptual approach in the study of budget management in the public regulation system.

Theoretical and methodological principles of the budget management development in the public regulation system is a subject of investigation.

Within the article, a set of general scientific and special research methods is used. The methods of analysis and synthesis, generalization and scientific abstraction in the formation of the conceptualcategorical apparatus were used. Abstract-logical method was used for the generalization of theoretical foundations of budget management; the method of system analysis was used to characterize the main components, functions, principles, techniques and methods of budget management; historical-logical method, the method of induction and deduction allowed exploring the conceptual approach to understanding the importance of budget management in the public regulation system; graphical method was used to visualize the results of the study.

The novelty of scientific results is specified in the following provisions:

- a conceptual approach «Entity-Relationship-Result» Management has been first proposed, on its basis, accordingly, a conceptual semantic model of budget management understanding in the public regulation system is developed, which includes regulatory support, functions, principles and complex of effective tools (methods, techniques, procedures), that will enhance the role of budget management in the development of strategic principles of budgetary policy and ensure functions fulfillment of public authorities and local selfgovernment bodies;

- a scientific approach to establishing classification features of budget management, reflecting its division by governing bodies, assigned tasks, content, management level, transparency degree, timing, term, performance level, implementation stage are proposed. It allowed to deepen the economic content of budget management, to find out its necessity, specificity and characteristics in the public regulation system. 


\section{Research of existing concepts of public administration}

Budget management is one of the directions of the state's management activity, a condition that ensures the synergy of the financial management system. As a kind of the state's management activity, budget management is designed to pierce its directions, ensuring their implementation and coherence in achieving the country's financial goals. Within the framework of budget management, there is a process of budgetary funds management, which management actors of all levels participate in. Today, budget management is widely used in financial science. However, in Ukraine the conceptual approach to budget management understanding in the public regulation system has not been formed yet. In addition, its place in the strategic principles development of budgetary policy has not been clarified. All the mentioned above affects the overall effectiveness of budget management in the formation and use of budgetary funds and the social and economic development of the country as a whole. Therefore, we propose to study budget management from the point of view of the world experience in the framework of the concepts implementation of public administration, and on their basis form a conceptual approach to understanding budget management in the public regulation system.

There are various conceptual approaches to management in the world that are used in the public sector, the most common of which are New Public Management, Good Governance, Multi-level Governance, Network Management i E-government.

New Public Management (NPM) is the art of managing the overall well-being of the nation-state as a whole (Hokayema, Kairouz, 2014). Its development began in the late 1970s and early 1980s. For the first time, this conceptual approach was used by the British Prime Minister Margaret Thatcher (Guttentag, Herring, 1984). More than 70 countries in the world are implementing NPM-based reforms.

The essence of NPM is to introduce all the best theories and practices used in business to the public management. There is no specific standard model of governance that would work in all countries. The most important parameters of the NPM conceptual approach are the transition from (Matei, 2006) politics to management; process management to result oriented management; collective provision of government or social services to flexible provision of specific services; centralized management to decentralized one; the traditional theory of public management to the up-todate one that responds to contemporary challenges and realities; rigid control methods to the flexible, resultoriented ones; selective management to a complex, ethically based one.

Good Governance (GG) involves close cooperation between the state, business and citizens, focusing on partnerships. The definition of Good Governance was introduced in 1992 for the first time (1992). The purpose of GG is to exacerbate the level of social inequality, reduce the role of the state in public relations. The main parameters of the GG are the right of all citizens to participate in management decisions; ensuring transparency in the management process; equality in managerial decision-making; ensuring efficiency and effectiveness in the management process; government accountability to citizens.

Multi-level Governance ( $M L G$ ) was established in the 1920s (Marks, 1993). This conceptual approach involves not only the vertical subordination of public authorities, but also interaction with other entities. Under this approach, peculiarities of constructing multi-level management structures are investigated and perspective directions for their development are determined (Juncos, Pomorska, 2010).

Network management (NM) provides management based on the formation of a new strategy of relations between the state and society, public and private spheres. This management is opposed to the monocentric system of public administration and the polycentric system of market competition. NM was founded in 1963 by two prominent Austrians F. Paul and O. Morgenstern (Peterson, 2003). The term «network» is often used to describe different clusters in management, that are related to one another in political, social or economic life. Such networks may be freely structured, but they still disseminate information (Peterson, O'Toole, 2001). Under such management, the main aspect is the network of its members, each of them is of interest and able to help, thus determining success or failure (Peterson, Jone, 1999). According to NM, the state is inferior to the leading position in the regulation of managerial relations and an equal agent of interaction in network management (Peterson, 2003).

E-government (e-Government) is the concept of public administration, its essence is to use modern ICT to ensure the efficiency and transparency of government, as well as public control over it. This conceptual approach not only provides information about public authorities, but also allows the population to take certain actions for which it had previously been forced to visit public institutions.

In most countries of the world when developing their own budget management concepts, these five conceptual approaches are combined through the selective adaptation of individual parameters of each of them, taking into consideration peculiarities of the budget system construction of each country, resource support of all levels of management, methods and mechanism of budgetary funds management. We would like to propose our own conceptual approach to understanding budget management in the public regulation system «EntityRelationship-Result» Management. This approach will allow us to identify causal linkages inherent in budget 
management in the public regulation system, and the place of budget management in the development of strategic principles of budgetary policy.

\section{Analysis of the proposed conceptual approach to the understanding of budget management in the state regulation system}

In modern Ukraine, there is no legislative document designed to regulate the principles of budget management. That is why the current state and local self-government bodies, when managing budget funds, rely on the following legislative and regulatory documents: the Constitution of Ukraine; the Budget Code of Ukraine; the Law of Ukraine on the State Budget; other laws governing budget relations; regulations of the Cabinet of Ministers of Ukraine; regulatory legal acts of central executive bodies; decisions of the authorities of the Autonomous Republic of Crimea, local state administrations, bodies of local selfgovernment. Insufficient management regulation impairs the quality of budget discipline, and the lack of proper regulatory support for budget management does not guarantee the elimination of identified offenses and the management focus on preventing them. The management action should start from the moment of the draft budget development and terminate at the end of the reporting period. In the process of budget management, its subjects should be useв as a set of methods and techniques that will continue to ensure a gradual transition from one type of management to another depending on the stage of the budget process when providing the budget management and how it is subject.

Today, there are different views on the essence of the economic concept of the «budget management», which differ from one another significantly. Different interpretation of the studied economic concept by scientists shows that they understand different tools of budget management, and therefore use different scientific approaches. Lack of theoretical guidance of the budget managementimpedesits adequate scientificunderstanding and does not contribute to the proper effectiveness of this phenomenon in practice. Therefore, we consider it necessary to analyze the scientific approaches we know to the essence of the economic concept of the «budget management $\gg$ and propose our own approach to its vision. Let's divide the assertions under consideration in accordance with their scientific approaches.

O. Borovykova (Borovykova, 2008), V. Oparin (Oparin, Safonova, 1998) and I. Tymchenko (Tymchenko, 2013) use an evolutionary scientific approach. It provides an opportunity to consider budget management from the point of view of its gradual development in society, that is, in the long-term retrospective, but not in the medium or short term, necessary for reforming the public sector or forecasting it. Functional scientific approach was used by L. Timirkhanova (Timirkhanova, 2007) and V. Fedosov (Fedosov, 2004), who primarily focus on management functions related to budgeting and budgetary funds use. In turn, T. Myronova (Myronova, Dobrovolska, Protsai, Kolodiy, 2006), V. Demyanyshyn (Demyanyshyn, 2008), S. Mykhailenko (Mykhailenko, 2010), and I. Avetisian (Avetisian, 2016) apply a systematic scientific approach, which involves the study of the phenomenon based on the principles of systematic approach, i.e. integrity, hierarchy, structuring, plurality, etc. We believe that this approach can be developed taking into consideration the emergence of new requirements for the budget process, i.e. complexity, publicity, transparency, complementarity, efficiency, etc.

One of the types of systematic scientific approaches comprehensive - was used in the study of the budget management nature by A. Baskakov (Baskakov, 2016), N. Yashyna (Yashyna, 2004).Their works are based on a comprehensive approach, which makes it possible to study all elements of the phenomenon. T. Kovaliova, A. Buriachenko and Ye. Malik (Malik, 2012) apply a standardization scientific approach when studying the essence of the economic concept of «budget management». It emphasizes the role of the phenomenon under study in achieving stability of the social and economic development of the country. At the same time, this scientific approach is insufficient in the context of the need to reform the budgetary sphere, as it is today in Ukraine.

Normative scientific approach was used by A. Premchand (Premchand, 1993) in understanding budget management as a set of actions related to the funds mobilization, setting priorities for government programs, effective funds management, control over their formation and use within the budget process in accordance with the current legislation. We believe that the normative approach must be complemented by the positive scientific approach, which involves the study of the actual state of the phenomenon under consideration. V. Fedosov, V. Oparin and L. Safonova (Fedosov, 2004) propose to characterize budget management from the standpoint of a logical scientific approach, which enabled them to distinguish the subjects, object and topic of the studied economic concept. In our view, their approach should be considered as a variation of the above systemic scientific approach.

L. Pankevych, M. Zvarych and P. Mogyliak (Pankevych, Zvarych, Mogyliak, 2006), A. Indutenko (Imdutenko, 2007) consider the essence of budget management based on an integrated scientific approach. This made it possible to distinguish the mechanism of its action, which deepens, on the one hand, the interaction of management entities and on the other hand the interconnections between the components of budget management. Process scientific approach was used by O. Yermakova (Yermakova, 2010). It enabled her to interpret budget management as a process of managing budgetary flows using scientifically sound market forms and decisionmaking methods in the area of management of budgetary 
assets, liabilities and budgetary risks. From our point of view, the process approach can be supplemented by a procedural scientific approach that allows detailing the rationale of management decisions in the public sector and giving them greater efficiency.

Against this background, we consider it fundamental to treat budget management as a set of interrelated functions, principles, methods, techniques and procedures used by the authorized bodies and are directed to the development and implementation of management decisions in drawing up, reviewing, approving, executing the budget of the state and the budgets of its territorial-administrative units to ensure efficient use of budgetary funds.

The budget management is an important instrument of state regulation of the public authorities' activity. The main goal of budget management is to increase the efficiency of budgeting and use of budgetary funds in accordance with the strategic objectives of social and economic development of the country. The object of budget management is budgetary funds, and subjects are the bodies of representative, legislative and executive power, which are vested with relevant rights and powers.

Currently there is no single approach to the study of the main components of budget management. However, most modern scholars agree with its features distinguished by V. Fedosov, V. Oparin and L. Safonova, who relate to them: managing the budget process, which includes budget planning and organization of budget fulfillment; accounting of budget fulfillment; control over budget fulfillment (Fedosov, 2004). Similar scientific approach is proposed by V. Demyanyshyn, who also focuses on budget planning, budget fulfillment, budget accounting and budget control (Demyanyshyn, 2008).

Having considered the mentioned above approaches to the components of budget management and considering that budget management is a complex, multilevel system, we propose our own approach to distinguishing its main components, i.e. budget projection, budget planning, accounting of budget fulfillment, reporting of budget fulfillment, budget control and budget support. In our opinion, budget support should include information, organizational, methodological and regulatory support.

We believe that information budget support provides a meaningful, reliable and operational information base that serves as a basis for making optimal management decisions about the formation and use of budgetary funds. For organizational budget support of the corresponding process, a set of internal structural services and units is created, which develop and make management decisions about the formation and use of budgetary funds and are responsible for their results. Methodological budget support means a set of approaches, methods, means, techniques and procedures that are used in the course of managing budgetary funds to achieve the primary objective of budget management.
In turn, regulatory budget support is a set of legal acts regulating budgetary relations in Ukraine regarding the effective formation of revenues and the efficient use of funds in the public sector.

The basis for the budget management development is its functions, principles and methods. Today, due to the lack of a separate document at the legislative level that would determine the peculiarities of budget management, the main managers use the narrow range of functions inherent in financial management in general, i.e. projection, planning, organization, analysis and control. Nevertheless, in fact, some of them are done formally. Therefore, it is necessary to investigate the known scientific approaches of domestic scientists that reveal the functions of budget management.

The budget management functions refer to the types of management activities in the formation and use of budget funds, as well as control over their movement. V. Fedosov, V. Oparin and L. Safonova distinguish the following functions of budget management: strategic planning, planning the implementation of strategies, organization of the developed plans implementation, accounting and control (Fedosov, 2004). Similar functions are generalized by V. Demyanyshyn (Demyanyshyn, 2007), V. Panteleyev (Panteleyev, 2013). In turn, L. Klets focuses on distributive, regulatory, stimulating, controlling and social functions (Klets, 2007).

V. Venger proposes to separate the following functions: distribution (redistribution), regulative and control (Venger, 2009). His scientific approach is supported by S. Mykhailenko, who states that through the distributive (redistributive) function, distribution and redistribution of certain economic goods (national wealth, GDP, national income, value) is implemented in society. Due to the manifestation of the regulating function, the organizational and managerial mechanism of the state's influence on various social and economic phenomena and processes is created and formed. The control function allows carrying out analyticalmonitoring and control-audit procedures in the sphere of public finances (Mykhailenko, 2011).

Summarizing the views of scientists on the budget management functions, we distinguish the following: projection, planning, organization, accounting, analysis, control and regulation.

The budget management is also based on certain principles. L. Pankevych, M. Zvarych, P. Mogyliak and B. Khomichak, by studying the principles of budget management, identified the principles of the budgetary system defined in the Budget Code of Ukraine (Pankevych, Zvarych, Mogyliak, 2006). V. Fedosov, V. Oparin, and L. Safonova have proposed the following list of principles to be studied (Fedosov, 2004): ensuring full and timely revenue generation as a whole and at each source separately; financing activities within the limits of the amounts approved in the budgets and during the fiscal year; proportionality when financed 
from the budget; legal entities financing solely from the budget; ensuring effective control over the proper use of budgetary resources; compliance with financial discipline at enterprises and organizations in the public sector.

In turn, S. Mykhailenko separates the following principles of budget management (Mykhailenko, 2011): scientific, systematic, unity, economy and efficiency, targeted use of budgetary funds, fairness, the combination of rights, duties and responsibilities, publicity and transparency. In her view, it is these principles that define the general rules of the process organization of budget management at all its milestones and stages, allowing to expand the scientific heritage of budget management. In our opinion, this approach is quite interesting.

The above scientific approaches, which reveal the principles of budget management, point to the lack of a unified approach, which would characterize general requirements for the theory construction of budget management. Therefore, we consider it necessary to supplement the existing principles with others that will reveal the primary underlying management of budget formation and use. We propose to include the below principles of budget management as follows: legality (definition and adherence to the main principles of budgetary funds management in accordance with the current legislation of Ukraine); continuity (continuity of management on formation and use of budgetary funds in accordance with strategic tasks of the social and economic development of the state); accessibility (public access to budget management results); responsibility (responsibility of state and local self-government bodies within the limits of the powers assigned to them for managing budgetary funds within the currentlegislation); completeness (budgetary funds management using the available tools in full according to the legislation of Ukraine); coherence (coordinated interaction of public authorities and local self-government bodies in the direction of ensuring effective management of budgetary funds); timeliness (the ability to identify gaps in the budget process in a timely manner, which may further affect the state of formation and use of budgetary funds); consistency (step-by-step budget funds management in accordance with the methodology and legislation in force in Ukraine); coordination (elimination of procedures duplication in managing the formation and use of budgetary funds); integrity (ensuring interconnection between public authorities and local governments, as well as between previous and current budget management results); reality (management that reflects the real results of managing the formation and use of budgetary resources); prudence (a degree of caution in formulating the conclusions necessary to make judgments on the budget management results without the existence of appropriate supporting facts).

The analysis of existing approaches to the consideration ofthepeculiarities ofthebudgetmanagementdevelopment revealed that scientists paid little attention to the budget management methods, which are an integral part of it. Most scientists associate management methods with control methods. We consider this approach debatable, since control is a function of management. Therefore, it is advisable to distinguish exactly the methods that are inherent in budget management. We propose to relate to them such methods: normative (based on the use of rules and regulations, according to which budgetary funds are managed); monitoring (provides for monitoring the formation and use of consolidated, state and local budgets, on the basis of which it is possible to determine the level of management effectiveness); functional (implies defining functional responsibilities of budget entities in relation to the management entity); supervision (involves management, which is built on collecting the necessary information about the state of formation and use of budgetary funds); regulatory (means setting limits to the management of budgetary funds in accordance with applicable law); survey (involves collecting information about the object and subjects of management during direct communication by registering responses).

The economic term «procedure» means an officially established or customary procedure for the implementation of anything. Against this background, the budget management process should be understood as an officially established procedure for managing budgetary funds, which presupposes a certain sequence of management actions in accordance with current legislation. By techniques, communication is understood as a means of transmitting something. Therefore, the methods of budget management are recognized as a set of connections between entities and management object, based on which some affect the others.

Today, in science, not enough researchers are paying attention to the classification features of budget management. Using own scientific developments (Melnychuk, 2016), we offer an enhanced proprietary approach with nine classification features, that allow you to explore budget management in all its manifestations: by governing bodies, assigned tasks, content, governance level, transparency degree, timing, term, performance level, implementation stage.

By governing bodies, we propose to separate state, departmental, internal economic and public budget management. State budget management should be understood as the management exercised by central government bodies in the course of the budget process, as well as to address other issues of national importance regarding the formation, distribution and use of budgetary funds. Departmental budget management involves the management carried out by the agencies for the formation and use of funds in the public sector. In-house budget management is characterized by the management within the institutions, organizations and other associations by relevant bodies within the budgeting, formation and use of budgets. In turn, public budget management involves a form of public 
participation in budget management, which is based on the accountability of public authorities and local selfgovernment bodies to citizens.

By assigned tasks, the budget management can be divided into strategic, tactical and operational. Strategic budget management aims to achieve long-term goals in the area of budget management, is provided for up to five years and is enshrined in the country's economic and social development budget programs. Tactical budget management ensures that medium-term budgetary goals and objectives are met within one fiscal year. In addition, operational budget management aims to achieve current budget management goals within one calendar month or quarter, consistent with minimum management periods.

By the content, we suggest dividing budget management into a comprehensive and organizational one. Comprehensive budget management aims to increase the efficiency of budgeting and budgetary funds use, as well as to identify deficiencies, violations, abuses in the budget system and to remedy them. Organizational budget management is intended to focus on budget management methodologies and creating prerequisites for its use by management entities based on the choice of forms of its organization, definition and distribution of functions between individual participants in the management process, ensuring the necessary coordination and recruitment, capable of practically fulfilling the functions and tasks of management as defined by applicable law.

By the governance level, we propose to distinguish such types of budget management as national and local ones. National budget management means the management of the formation and use of budgetary funds, carried out by public authorities. Local budget management involves managing the formation and use of budgetary funds by local governments.

By transparency level, budget management should be divided into transparent and non-transparent. Transparent budget management means informing the public about the ongoing activities of public authorities and local governments, explanation of certain management decisions in terms of their expediency to the population. In turn, non-transparent budget management involves management that is incapable of preventing corruption in the formation and use of budgetary funds and is not based on managerial organizational measures, which provide for procedures that do not allow for variations in the budget process.

By timing, we suggest separating the preliminary, current, periodic and subsequent budget management. Preliminary budget management involves management, which is carried out before the processes of planning, drafting, review and approving the budget in the direction of negative phenomena elimination, which may result in a decrease in budgetary revenue or misuse of budgetary funds. Current budget management is the constant development of concrete measures that give the state and local self-government bodies the ability to form effectively budgetary funds and use them efficiently in order to ensure the social and economic development of the country and meet the needs of society. Periodic budget management should be understood as management, which requires the authorities to find out how effective the formation and use of funds in the public sector take place in a given period. Subsequent budget management is performed after the financial operations are completed, when the budget period is over, which main purpose is to establish the correctness, legality and economic feasibility of the formation and use of funds in the public sector.

By terms, budget management should be divided into urgent and non-urgent. Urgent budget management is a type of the budget management, which requires general government to complete the tasks assigned to them promptly and effectively. Non-urgent budget management implies a type of budget management that requires general government to perform their tasks effectively over a period of time.

By the performance level, budget management should be divided into effective and ineffective. Effective budget management means ensuring the efficiency of budgeting and use of budgetary funds in accordance with the strategic objectives of the state's social and economic development. In turn, ineffective budget management involves certain measures implemented by general government, which summarize results under which the effectiveness of the formation and use of budgetary funds is not ensured.

By the implementationstage, the following types of budget management as legislative, regulatory, implementation and subsequent should be distinguished. Legislative budget management envisages management, which aims to check the compliance of the state authorities with the basic legislation on the terms of submission, registration of the draft Law of Ukraine $\ll$ On the State Budget of Ukraine» and its adoption. Regulatory budget management is carried out during the review and approval of the budget in accordance with the established parliamentary regulations. Authorized bodies, agencies and the parliament carry out implementation budget management at the stages of the budget implementation and revision. Subsequent budget management implies the use by the special bodies or parliamentary committees of a set of methods and techniques in auditing the financial statements of budget execution.

The proposed approaches to establishing classification features of the budget management make it possible to deepen the economic content of budget management, find out its necessity, specificity and characteristics in the system of state regulation and structural elements. The study of theoretical bases of the budget management development in the public regulation system based on the conceptual approach has allowed revealing the basic regularities of the budget management development in the public regulation system and defining its structural 


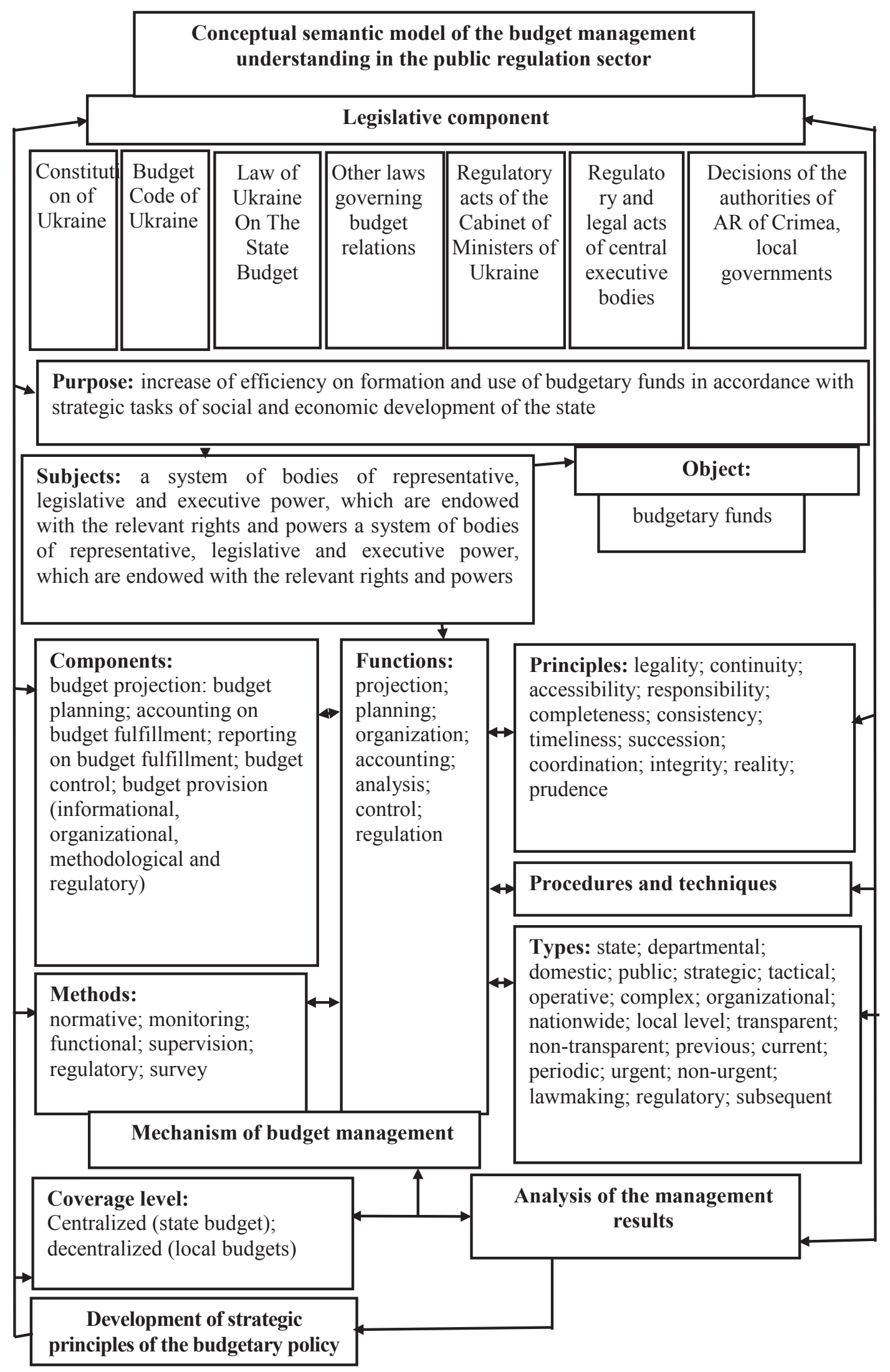

Figure 1. Conceptual semantic model of the budget management understanding in the public regulation system

Source: proposed and compiled by authors 
elements. This contributed to the construction of a conceptual semantic model of the budget management understanding in the public regulation system, which explores it holistically (Figure 1).

This approach deepens the theoretical understanding of budget management and determines its place in the development of strategic principles of budgetary policy. The proposed model reflects the list of components of budget management in the public regulation system, their close relationship and consistency, and aimed at ensuring the performance of the function of public authorities and local self-government bodies. Thus, the purpose of governance depends on the legislative component, which is the basis of public regulation of budget management. The same can be said about the purpose of management, which determines the main list of effective tools used by the entities when influencing a management object to achieve the desired result. Methods, techniques, procedures of budget management are the effective tools by which management is directed towards achievement of strategic principles of budgetary policy.

Thus, the conducted research made it possible to offer a conceptual approach «Entity-Relationship-Result» Management, which allowed to reveal the main trends in the budget management development in the public regulation system, investigate its structural components holistically and on its basis to develop a conceptual semantic model of the budget management understanding in the public regulation system, reflecting the list of the budget management components in the public regulation system, their close relationship and coherence.

Thus, it is proved that, although budget management is widely used in financial science, a conceptual approach to its understanding has not been formed yet. Critical analysis of the literature has made it possible to substantiate that conceptual approaches are used in the study of budget management, which do not allow revealing all its peculiarities fully.

\section{Conclusions}

Therefore, budget management is one of the tools to overcome problems, which arise in the process of formation and use of budget funds in the conditions of their scarcity. The matter of justification of optimal and effective methods and tools of effective budgetary management is important not only for Ukraine but also for other states, particularly in the post-Soviet space. At the same time, the global experience does not give universal decisions on the budget management organization, since each state has its own budgetary system, peculiarities of building a budgetary system and its conceptual management approaches that can be used in the budgetary sphere (New Public Management, Good Governance, Multi-level Governance, Network Management and E-government).

We have proposed our own conceptual approach «Entity-Relationship-Result» Management, which made it possible to reveal the main trends in the budget management development in the public regulation system, identify its structural elements, deepen the essence of budget management (a set of interrelated functions, principles, methods, techniques and procedures used by the authorized bodies and aimed at the development and implementation of management decisions in drawing up, reviewing, approving, executing the budget of the state and the budgets of its territorialadministrative units to ensure efficient use of budgetary funds), offer scientific approaches to understanding the components, principles of budget management, state own vision of its methods and classification features. This helped to build a conceptual semantic model of the budget management understanding in the public regulation system. The proposed model reflects the list of the budget management components in the public regulations system, their close interconnection and coherence, which are aimed at ensuring the functions performance of public authorities and local selfgovernment bodies.

\section{References:}

Avetisian, I. A. (2016). Biudzhetnyi menedzhment: sushchnost, istoriia i problemy sovershenstvovaniia $\mathrm{v}$ sovremennoi Rossii [Budget management: essence, history and problems on improvement in modern Russia]. Problemy razvitiia territorii - Problems of the territory development, 2(82), 137-153. (in Russian)

Babinova, O. O. (2007). Kriterii otsinky efektyvnosti diialnosti orhaniv mistsevoho samovriiaduvannia: svitovyi dosvid ta Ukraina [Criteria for evaluating the performance of local governments: world experience and Ukraine]. Stratehichni priorytety - Strategic Priorities, 2(3), 73-79. (in Ukrainian)

Baskakov, A. Yu. (2016). Naukovi pidkhody do vyznachennia ekonomichnoho zmistu ponittia «biudzhetnyi menedzhment» [Scientific approaches to the definition of the economic concept of «budget management»]. Naukovi zapysky Natsionalnoho universytetu «Ostrozka akademiia». Seriia «Ekonomika» - Scientific notes of the National University «Ostrog Academy». Series «Economics», 3(31), 92-95. (in Ukrainian)

Bogolib, T. M. (2015). Biudzhetna polityka yak instrument makroekonomichnoi stabilnosti [Budgetary policy as an instrument of macroeconomic stability]. Ekonomichnyi chasopys XXI - Economic Journal-XXI, 3-4(1), 84-87. (in Ukrainian)

Borovikova, Ye. V. (2008). Teoretiko-metodologicheskie polozheniia orzanizatsii biudzgetnogo menedzhmenta [Theoretical and methodological provisions of the budget management organization]. Finansy $i$ kredit - Finances and Credit, 11, 32-34. (in Russian) 
Fedosov, V. (Ed.) (2004). Biudzhetnyi menedzhment [Budget Management]. Kyiv: KNEU. (in Ukrainian) Malik, S. O. (Ed.) (2012). Biudzhetnyi menedzhment [Budget Management]. Kyiv. (in Ukrainian) Venger, V. V. (2009). Finansy [Finances]. Kyiv: Center of Educational Literature. (in Ukrainian)

Demianyshyn, V. (2007). Skladannia proektu biudzhetu derzhavy: prahmatyka, problematyka ta shliakhy udskonalennia [Development of the draft state budget: pragmatics, problems and ways for improvements]. Svit finansiv - The World of Finances, 4(13), 100-115. (in Ukrainian)

Demianyshyn, V. (2008). Teoretychni zasady biudzhetnoho mekhanizmu derzhavy [Theoretical foundations of the state's budget mechanism]. Visnyk Kyivskoho natsionalnoho torhovelno-ekonomichnoho universytetu - Bulletin of the Kyiv National University of Trade and Commerce, 1, 56-67. (in Ukrainian)

Yermakova, Ye. A. (2010). Biudzhetnyi menedzhment i ego funktsionalnye elementy [Budget management and its functional elements]. Finansy i kredit - Finances and Credit, 20, 2-7. (in Russian)

Indutenko, A. N. (2007). Biudzhetnyi menedzhment $\mathrm{v}$ usloviiakh formirovaniia sistemy biudzhetirovaniia, orientirovannogo na rezultat [Budget management in the conditions of the creating the result-oriented budgeting system]. Finansy i kredit - Finances and Credit, 30, 2-8. (in Russian)

Klets, L. Ye. (2007). Biudzhetnyi menedzhment [Budget Management]. Kyiv: Center of Educational Literature. (in Ukrainian)

Kovaleva, T. M. (2003). Osnovy orzanizatsii biudzhetnogo menedzhmenta v subekte Federatsii [Foundations of the budget management organization in the entity of the Russian Federation]. Finansy i kredit - Finances and Credit, 6, 141-146. (in Russian)

Myronova, T. L., Dobrovolska, O. P., Protsai, A. F., \& Kolodiy, S. Yu. (2006). Upravlinnia rozvytkom rehionu [Management of the region development]. Kyiv: Center of Educational Literature. (in Ukrainian)

Mykhaialenko, S. V. (2010). Biudzhetnyi menedzhment: stan ta otsinka efektyvnosti [Budget management: state and efficiency evaluation]. Odessa: VVV, Druk Pivden. (in Ukrainian)

Mykhailenko,S.V.(2011).Biudzhetnyimenedzhment:vyznachennia, pryntsypy, funktsii[Budgetmanagement: definitions, principles, functions]. Aktualni problemy ekonomiky - Topical Issues of Economics, 3(117), 223-229. (in Ukrainian)

Oparin, V. M., \& Safonova, L. D. (1998). Sutnist ta skladovi biudzhetnoho menedzhmentu [Essence and components of budget management]. Finansy Ukrainy - Finances of Ukraine, 2, 60-67. (in Ukrainian)

Pankevych, L. V., Zvarych, M. A., \& Mohyliak, P. Ya. (2006). Biudzhetnyi menedzhment [Budget Management]. Kyiv. (in Ukrainian)

Pantelieiev V. P. (2013). Biudzhetnyi menedzhment [Budget Management]. Kharkiv: KhNU named after V. N. Karazin. (in Ukrainian)

Timirkhanova, L. M. (2007). Soderzhanie biudzhetnoho menedzhmenta [Content of budget management]. Vestnik Udmurtskogo universiteta - Journal of Udmurtia University, 2, 255-258. (in Russian)

Tymchenko, I. O. (2013). Rehionalnyi menedzhment [Regional Manegement]. Retrieved from: http://zavantag.com/docs/2247/index-634793.html?page=1 (accessed 21 September 2019).

Iashyna, N. I. (2004). Teoreticheskie i metodicheskie osnovy upravleniia biudzhetom: riski dokhodnoi chasti biudzheta [Theoretical and methodological foundations of budget management: risks to the revenue part of the budget]. Finansy i kredit - Finances and Credit, 8(146). Retrieved from: http://www.fin-izdat.m/journal/fc (accessed 21 September 2019).

Guttentag, J. R., \& Herring, J. (1984). Credit rationing and financial disorder. Journal of Finance, 39(5), 1359-1382. Hokayema, J., \& Kairouzb, A. (2014). Euro-Med: Public Management and Good Local Governance. ProcediaSocial and Behavioral Sciences, 528-535.

Juncos, A., \& Pomorska, K. (2010). Secretariat, facilitator or policy entrepreneur? Role perceptions of officials of the Council Secretariat. European Integration online Papers, 14(7), 26.

Marks, G. (1993). Structural policy and multi-level governance in the EC. In A. Cafruny and G. Rosenthal (Eds.). The State of the European Community: The Maastricht Debate and Beyond. Boulder.

Matei, L. (2006). Management public (2nd ed.). Bucharest.

Melnychuk, N. (2016). Budget management types under the current conditions. Intellectual Archive, 5(4), 63-72. Toronto: ShinyWordCorp., Canada.

Peterson, J., \& Jone, E. (1999). «Decision Making in an Enlarging European Union» in Sperling, J. (Ed.) Two Tiers or Two Speeds? The European Security Order and the Enlargement of the European Union and NATO. Manchester and New York: Manchester University Press.

Peterson, J., \& O'Toole, Jr. L. J. (2001). Federal Governance in the United States and the European Union: a Policy Network Perspective. In K. Nicolaïdis, R. Howse (Eds.), The Federal Vision: Legitimacy and Levels of Governance in the United States and the European Union. Oxford.

Peterson, J. (2003). Policy Networks. Politikwissenschaft. Political Science Series. Vienna, 6. Retrieved from: https://www.ihs.ac.at/publications/pol/pw_90.pdf (accessed 21 October 2019).

Premchand, A. (1993). Public Expendimre Management. Washington: IMF.

World Bank Governance for Sustainable Human Development (1992). Proceedings of the World Bank Annual Conference on Development Economics. 